\section{Suspensions and Expulsions in New Zealand State Schools}

\section{CATHy CASEY}

\section{Abstract:}

School suspensions have recently raised much public comment. Suspending a student's education is the most serious disciplinary step that a principal and board of trustees can take. In this paper Cathy Casey enters the debate on school suspensions and expulsions. First, she examines the current statutory requirements on school principals and boards of trustees in state schools in suspending or expelling a student. She then analyses the latest available New Zealand figures on notified suspensions and expulsions. Noting the limitations imposed by the data, she identifies several alarming trends. Finally, she discusses some controversial suspension issues, including the use of the "kiwi suspension" and the ramifications of two recent legal challenges to suspensions in the High Court of New Zealand.

S ince the inception of Tomorrow's Schools, there has been much public comment about school suspensions and expulsions. There has however, been little research or analysis of the phenomena. The first part of this paper examines the current legislative requirements on school principals and boards of trustees in state schools relating to specified and unspecified suspensions and expulsions. In the second part I analyse the latest available figures on suspensions and expulsions lodged with the Ministry of Education. Finally, I address some of the problems which principals and boards of trustees in state schools currently faced in 1993 when dealing with suspension and expulsion issues.

\section{Suspensions \& Expulsions - the Legislative Requirements}

The Education Act 1989 states that every New Zealander is entitled to free education at any state school from the age of five to the age of 19 and that principals and boards of trustees will

take all reasonable steps to ensure all students have assistance to remain at school and progress with their learning. (Ministry of Education, 1991, p. 3)

If problems arise that prevent or slow a student's progress through the school or harm the student's relationship with teachers and other students, Section $77 \mathrm{~b}$ of the Act states that the principal must take all reasonable steps to ensure that the student's parents are kept informed. This ensures that parents are involved in the problem and enables them to exert whatever parental authority and family resources they can to try to assist the school in dealing with the student. ${ }^{1,2}$

Section 77a of the Education Act states that school principals must take reasonable steps to ensure that students get good guidance and counselling. A student who has an ongoing behavioural problem at school therefore, should have received counselling from the school guidance counsellor to help him or her resolve the situation. ${ }^{3,4}$

These two provisions of the Act - that parents be kept informed and that students receive good guidance and counselling - have important consequences if the principal or board of trustees decides to suspend the education of a student who has had ongoing problems at the school. If ongoing problematic behaviour leads to a student's suspension, according to the Act, it should mean that he or she has reached the final step in a long, consultative process. To withdraw a student's right to learn at his or her chosen school is a most serious step. Indeed, the Ministry states that: 
Suspension for an indefinite period is the final and most serious disciplinary measure open to a principal (Ministry of Education, 1991, p. 15)

In legal terms, a suspension is the formal procedure by which a principal can withdraw from any student the right to attend the school at which the student is enrolled. Sections 13 to 19 of the Education Act 1989 deal with the suspension of students, setting out the grounds upon which a principal may suspend a student and the procedures to be followed by a school.

Section 13 of the Act states that a suspension can be for a specified period (up to three days) or for an unspecified period (that is for a period to be specified by the board of trustees). The grounds for suspension are either that:

i) the student's gross misconduct or continual disobedience is a harmful or dangerous example to other students or

ii) because of the student's behaviour, it is likely that the student or other students will be seriously harmed if the student is not suspended.

As stated above, explicit in the Act is the obligation of schools to have informed parents of ongoing problems with a student and to have offered the student counselling to help alleviate the problem.

Gross misconduct on the other hand, may be committed by a student who has previously had a completely trouble-free life at school. In such a case, it is worth noting that there may have been no opportunity for the school to have carried out the supportive actions provided for in the Act.

When a student is suspended - whether for a specified or unspecified period - there are statutory requirements placed upon the principal to give notice of the suspension. Section 14 of the Act requires that the principal immediately advise the board, the Ministry of Education and the parents of the student (unless the student is over 20 years):

a) that a suspension has occurred

b) why the suspension has occurred

c) whether it is for a specified or an unspecified period and if specified, what the period of time of the suspension is for.

In the case of a specified suspension (up to three days), the day the suspension occurs and any non-school day do not count. If the suspension is for a specified period, the board of trustees cannot extend it. The board can however, lift the suspension before the specified period has expired. This can only happen however, if boards of trustees are advised immediately of the specified suspension. Often this does not happen. While the chairperson of a board may be advised by the principal, generally board of trustees members do not receive any such notification. So, although the 1989 Education Act gives the board the power to uplift the specified suspension, failure to inform the board will result in board members having no opportunity to consider the principal's decision and if necessary, intervene.

The specified suspension therefore, would generally not be considered by the board of trustees unless the student had already received a specified suspension within the same calendar year. In such a case a student would have to be suspended by the principal for an unspecified period. The unspecified suspension then becomes a board matter.

A parent of any student suspended for a specified period has the right to ask the principal for a meeting to discuss the situation, and has the right to ask the principal for a Ministry of Education representative to be present at that meeting. It is the principal's decision as to whether the student is suspended for a specified or an unspecified period.

In the case of an unspecified suspension, the Education Act prescribes different courses of action for boards to take if the student is under the age of 16 . (The age of compulsory schooling 
was extended to 16 years on 1 January, 1993). Under the age of 16, an unspecified suspension may be extended, but the student cannot be expelled. Over the age of 16, an unspecified suspension cannot be extended. Expulsion of the student then becomes one of the options. The other statutory requirement placed upon the principal under Section 14 is that the board be provided with a full written report on the circumstances of the suspension as soon as practicable.

In dealing with any suspension, boards of trustees also have statutory responsibilities which must be followed.

If a student under the age of 16 is suspended for an unspecified period, the board may

i) lift the suspension at any time before it expires (either unconditionally or subject to any conditions it wants to set)

ii) from time to time extend the suspension (for a period determined by the board when extending the suspension) if it has not already been lifted or expired.

Section 16 (9) of the Act requires that if the board uplifts the unspecified suspension of a student under 16 , the student's name must remain on the school roll. If the suspension is upheld, the student's name stays on the register until the earliest of the following days:

- the day on which the suspension expires;

- the day on which the student is enrolled at a registered school;

- the day on which the student is given an exemption under Section 22 of the Education Act.

For students over 16, the same rules apply with three further options for removing the student's name from the roll:

- the day on which the student is expelled;

- the day on which the student leaves school;

- the first day of January after the student's 19th birthday.
There is an obligation for the board of trustees to meet within seven days of the student's period of unspecified suspension. If the suspension has not been uplifted or extended by the board within seven days, the suspension is deemed lifted and the student can return to school.

A board may appoint a disciplinary committee which can act under delegated authority. Such a committee will generally report back to the board on its actions.

Under Section 16 (2) (a) of the Act, a board (or disciplinary committee of the board) may not lift or extend the unspecified suspension of a student under the age of 16 without taking all reasonable steps to give the student's parents notice of

i) the time and place of the meeting where the board will decide whether to lift or extend the suspension and

ii) the fact that any parent may attend the meeting (with or without a representative) and that any parent or parent's representative may speak about the suspension, and whether it should be lifted or extended, before the board decides.

Before making their decision, 16 (2) (b) of the Act states that the board must consider the principal's written report on the circumstances of the suspension and everything said by the parents or parents' representative at the meeting.

Should the board decide to extend the unspecified suspension of a student under the age of 16 , the principal must try to enrol the student in a suitable school which the student can conveniently attend. If a place at another suitable school cannot be secured, the principal must inform the Ministry of Education of the steps taken to try to enrol the student. In such cases, under Section 16 (7) of the Act the Ministry has the power to

i) direct another school to enrol the student (this would override any zoning or enrolment scheme in place) 
ii) lift the suspension if it feels it to be appropriate

iii) direct the parents to enrol the student in the Correspondence School.

The main statutory differences for boards in dealing with a student over the age of 16 who is suspended for an unspecified period, is that as well as being able to lift the suspension (unconditionally, or subject to any conditions) it is also able to expel the student. If the student is expelled, the principal does not have to find an alternative school for him or her.

This exhausts the statutory requirements on the principal and the board relative to specified and unspecified suspensions. The procedures detailing how a board is to meet its statutory requirements and how suspensions are to be handled are decided upon by the individual board.

\section{Suspensions and Expulsions under Tomorrow's Schools}

The Education Act (1989) requires that state schools notify the Secretary for Education of all suspensions. In practice, this means that the school principal advises the local office of the Ministry of Education. There is no statutory requirement for the Ministry to be provided with information on either the gender or the ethnic background of the suspended student. Since mid-991 however, the Ministry has requested that schools provide it with this extra information.

The total number of students in New Zealand state primary, intermediate and secondary schools has grown by 2,524 since 1991.

Table 1 NZ State School Population by School Sector

\begin{tabular}{cccccc}
\hline & Prim/Intm & Secondary & Total & Variance & $\%$ \\
\hline $\mathbf{1 9 9 1}$ & 416,084 & 228,689 & 644,773 & & \\
$\mathbf{1 9 9 2}$ & 417,401 & 227,912 & 645,313 & +540 & 0.1 \\
$\mathbf{1 9 9 3}$ & 423,510 & 223,787 & 647,297 & +1984 & 0.3 \\
\hline
\end{tabular}

Analysed more fully, it can be seen that over the three years, the number of students in primary and intermediate education increased by 7,426, while the number of students in the secondary sector decreased by 4,902 . The gender balance of the school population stayed constant over the three years - males $51 \%$, females $49 \%$.

The ethnic background of students in the New Zealand school population has maintained a constant percentage ratio over the last three years. European and "other" students account for around $73 \%$, Maori students presently make up 20\% and Pacific Islanders comprise around $7 \%$ of the school population.

Table 2 NZ State School Population by Ethnicity

\begin{tabular}{ccccc}
\hline & Maori & Pacific Island & European/Other & Total \\
\hline $\mathbf{1 9 9 1}$ & $119,771(18.6 \%)$ & $43,643(6.8 \%)$ & $481,359(74.7 \%)$ & 644,773 \\
$\mathbf{1 9 9 2}$ & $126,176(19.6 \%)$ & $43,694(6.8 \%)$ & $475,443(73.7 \%)$ & 645,313 \\
$\mathbf{1 9 9 3}$ & $129,967(20.1 \%)$ & $44,004(6.8 \%)$ & $473,956(73.2 \%)$ & 647,297 \\
\hline
\end{tabular}

Further analysis reveals that while numbers of Maori and Pacific Island students are increasing, numbers of European and "other" students are decreasing.

Table 3 Variance of the NZState Secondary School Roll 1991-1993 by Ethnicity

\begin{tabular}{lcc}
\hline & Roll variance & $\%$ \\
\hline Maori & $+10,196$ & +8.5 \\
Pacific Island & +361 & +0.8 \\
European & $-7,403$ & -1.5 \\
\hline
\end{tabular}

The Ministry of Education must be notified of all suspensions whether specified or unspecified. (Note that the 1993 suspension figures are only available to the end of June 1993. An estimate for 
the whole year has been projected by doubling this figure and is indicated by one asterisk).

There are a number of reasons why these figures may not accurately reflect the actual number of suspensions in New Zealand state schools. First, not all suspensions are notified to the Ministry of Education. Second, a suspension case may not reach the board of trustees if the principal decides to use the "kiwi suspension" as an alternative. The kiwi suspension occurs when parents are pressured by a principal into withdrawing the errant student from the school instead of having the student face a board of trustees disciplinary committee and a possible unspecified suspension.

Another form of the kiwi suspension known to be used by schools with boarding hostels is to expel the student from the hostel. While this is not a school suspension, expulsion from a boarding hostel can leave the student's parents with little alternative but to withdraw the student and place him or her at another boarding school.

The Ministry of Education is critical of the use of the kiwi suspension in New Zealand schools:

... it effectively deprives a student and his or her parents of their right to put their point of view to the board and argue reinstatement. It also deprives the student of the safeguards that the Act provides for the student's continued education. (Ministry of Education, 1991, p. 7)

At present, there is no research to indicate how widespread is the use of such informal suspension mechanisms.

The usefulness of the Ministry's notified suspension figures is limited because there is no breakdown by age of suspended students. What age were the suspended students in the primary/ intermediate group? How many younger primary students were suspended? Was suspension an option used for children aged five and six?
Another limitation of the present statistics is that we are given no indication as to how long the unspecified suspension was. It could be anything from four days to a suspension of several years. How many of the present notified unspecified suspensions were of a duration that would require the student to be re-enrolled at another school?

The information is also limited in that the figures identify national rather than regional trends. There is no breakdown available of the way in which different schools use suspensions. Are there any major differences between schools and therefore between principals? If so, do parents have the right to know so that they can use that in their assessment of the school prior to enrolment?

Over the last three years, there has been a steady increase in the number of notified suspensions. In 1991, there were 4,297 suspensions. This increased by $18 \%$ in 1992 . Projected suspension figures for 1993 indicate a $12 \%$ * increase.

Table 4 Total Suspensions from NZ State Schools

\begin{tabular}{lccl}
\hline & Total Suspensions & Variance & $\%$ \\
\hline $\mathbf{1 9 9 1}$ & 4,297 & & \\
$\mathbf{1 9 9 2}$ & 5,082 & +785 & +18 \\
$\mathbf{1 9 9 3}^{*}$ & $5,700^{*}$ & $+618^{*}$ & $+12^{*}$ \\
\hline
\end{tabular}

Returning to the New Zealand school population figures (Table 1) it can be seen that the number of school suspensions is increasing at a rate far greater than the increasing number of students in the school population.

Table 5 Variance of the NZ State School Roll Compared with Variance in the Number of Notified Suspensions 1991-1993

\% Variance in Roll $\%$ Variance in Suspensions

\begin{tabular}{lll}
\hline $\mathbf{1 9 9 1 - 1 9 9 2}$ & +0.1 & +18 \\
1992-1993* $^{*}$ & $+0.3^{*}$ & $+12^{*}$
\end{tabular}


Compared against their own populations, suspensions have increased at a rate of nearly one student in 1000 since 1991.

Table 6 Total Suspensions from NZ State Schools

\begin{tabular}{lccc}
\hline & Suspensions & School Population & $\%$ \\
\hline $\mathbf{1 9 9 1}$ & 4,297 & 644,773 & 0.7 \\
1992 & 5,082 & 645,313 & 0.8 \\
$\mathbf{1 9 9 3}^{*}$ & $5,700^{*}$ & 647,297 & 0.9 \\
\hline
\end{tabular}

In 1992, by far the biggest proportion (69\%) of notified suspensions were suspensions for a specified period (up to three days).

Table 7 Total Specified Suspensions from NZ State Schools

\begin{tabular}{lcll}
\hline & Specified & All & $\%$ \\
\hline $\mathbf{1 9 9 1}$ & 3,051 & 4,297 & 71 \\
$\mathbf{1 9 9 2}$ & 3,487 & 5,082 & 69 \\
$\mathbf{1 9 9 3}^{*}$ & $3,996^{*}$ & $5,700^{*}$ & $70^{*}$ \\
\hline
\end{tabular}

Table 8 shows that specified suspensions are increasing at an annual rate of around $14 \%$. This associated increase in workload falls directly onto the shoulders of school principals.

Table 8 Trends in Total Specified Suspensions from NZ State Schools

\begin{tabular}{lccc}
\hline & Specified & Variance & \% Variance \\
\hline $\mathbf{1 9 9 1}$ & 3,051 & & \\
$\mathbf{1 9 9 2}$ & 3,487 & +436 & +14.3 \\
$\mathbf{1 9 9 3}$ & $3,996^{*}$ & $+509^{*}$ & $+14.6^{*}$ \\
\hline
\end{tabular}

Unspecified suspensions account for about 30\% of all suspensions in New Zealand schools.
Table 9 Total Unspecified Suspensions from NZ State Schools

\begin{tabular}{lccc}
\hline & Unspecified & Al1 & $\%$ \\
\hline $\mathbf{1 9 9 1}$ & 1,246 & 4,297 & 29 \\
1992 & 1,595 & 5,082 & 31 \\
$1993^{*}$ & $1,704^{*}$ & $5,700^{*}$ & $30^{*}$ \\
\hline
\end{tabular}

Further analysis of unspecified suspensions over the last three years indicates that while there is an increase in the use of the unspecified suspension, it is more difficult to predict trends. There was an alarming $28 \%$ increase in unspecified suspensions between 1991 and 1992, but the estimates for 1993 reveal that the increase may have slowed. Such variance probably reflects the unpredictable nature of the student body and their sporadic engagement in actions defined by a principal as "gross misconduct". From the Ministry figures we are unable to ascertain how many of the unspecified suspensions were for "gross misconduct", "continual disobedience" or "behaviour likely to cause serious harm".

Table 10 Trends in Total Unspecified Suspensions from NZ State Schools

\begin{tabular}{lccc}
\hline & Unspecified & Variance & \% Variance \\
\hline $\mathbf{1 9 9 1}$ & 1,246 & & \\
$\mathbf{1 9 9 2}$ & 1,595 & +349 & +28 \\
$\mathbf{1 9 9 3}^{*}$ & $1,704^{*}$ & $+109^{*}$ & $6.8^{*}$ \\
\hline
\end{tabular}

In 1991 there were 175 expulsions from New Zealand secondary schools and 120 in 1992 - a decrease of $31 \%$ in absolute terms. Projected figures for 1993 indicate that the number of expulsions is continuing rapidly to decline. Since no further breakdown of these figures is available at present, it is difficult to hypothesise as to why the expulsion is becoming less popular. Did the change to the Education Act in January 1993 to extend the age of compulsory schooling from 15 to 16 make a difference to 
the number of students expelled? Are fewer students over the age of 16 getting into trouble? Are students over the age of 16 who are getting into trouble now being dealt with more leniently by boards?

Analysis of the notified figures indicates that the use of suspension by principals and boards is largely a secondary school phenomenon. In 1992 approximately 93.5\% of all notified suspensions took place in secondary schools.

Table 11 Total Suspensions from NZ State Schools by School Sector

\begin{tabular}{llll}
\hline & Prim/Intm & \multicolumn{1}{c}{ Secondary } & Total \\
\hline $\mathbf{1 9 9 1}$ & $269(6 \%)$ & $4,028(94 \%)$ & 4,297 \\
$\mathbf{1 9 9 2}$ & $328(6.5 \%)$ & $4,754(93.5 \%)$ & 5,082 \\
$\mathbf{1 9 9 3}^{*}$ & $414(7.3 \%)^{*}$ & $5,286(92.7 \%)^{*}$ & $5,700^{*}$ \\
\hline
\end{tabular}

Although there are far fewer suspensions in primary and intermediate schools than in secondary, Table 12 shows that the numbers of suspensions of primary and intermediate students is increasing at an alarming rate.

Table 12 Total Suspensions from NZ State Primary and Intermediate Schools

\begin{tabular}{lccc}
\hline & Prim/Intm & Variance & \% Variance \\
\hline $\mathbf{1 9 9 1}$ & 269 & & \\
$\mathbf{1 9 9 2}$ & 328 & +59 & +22 \\
$1993^{*}$ & $414^{*}$ & $+86^{*}$ & $+26^{*}$ \\
\hline
\end{tabular}

When compared with the variance in the New Zealand primary and intermediate school roll, it can be seen that the percentage increase in the use of suspensions is not commensurate with the percentage increase of the primary and intermediate school population.

Table 13 Variance of the NZState Primary and Intermediate School Roll, and the Variance in the Number of Notified Suspensions 1991-1993

\begin{tabular}{lcc}
\hline & \% Variance in Roll & $\%$ Variance in Suspensions \\
\hline $\mathbf{1 9 9 1 - 1 9 9 2}$ & +0.3 & +22 \\
1992-1993* $^{*}$ & $+1.4^{*}$ & $+26^{*}$ \\
\hline
\end{tabular}

Analysing the total number of suspensions against the primary and intermediate student population, suspension is still used very infrequently in primary and intermediate schools. In 1992, only eight primary students in every 10,000 were suspended. There is however, evidence that numbers of primary and intermediate students being suspended is increasing.

Table 14 Total Suspensions in NZ State Primary and Intermediate Schools, by School \{Population

\begin{tabular}{lccc}
\hline & $\begin{array}{c}\text { Primary/Intermediate } \\
\text { Suspensions }\end{array}$ & $\begin{array}{c}\text { Primary/Intermediate } \\
\text { Population }\end{array}$ & $\%$ \\
\hline $\mathbf{1 9 9 1}$ & 269 & 416,084 & 0.06 \\
$\mathbf{1 9 9 2}$ & 328 & 417,401 & 0.08 \\
$\mathbf{1 9 9 3}$ & $414^{*}$ & 423,510 & $0.10^{*}$ \\
\hline
\end{tabular}

Unspecified suspensions in primary and intermediate schools were very infrequent. In 1991 and 1992, only three in 10,000 primary and intermediate school students received unspecified suspensions from boards of trustees. 1993 estimates indicate a small increase. 
Table 15 Unspecified Suspensions from NZ State Primary and Intermediate Schools, by School Population

\begin{tabular}{lccc}
\hline & Unspecified Suspensions & School Population & $\%$ \\
\hline 1991 & 113 & 416,084 & 0.03 \\
1992 & 130 & 417,401 & 0.03 \\
1993* $^{130}$ & $206^{*}$ & 423,510 & $0.05^{*}$ \\
\hline
\end{tabular}

Suspensions were used with much more frequency in secondary schools. In 1992, there were 4,754 suspensions which means that approximately two secondary students in every 100 were suspended.

Table 16 Total Suspensions from NZ State Secondary Schools, by School Population

\begin{tabular}{lccc}
\hline & Secondary Suspensions & School Population & $\%$ \\
\hline $\mathbf{1 9 9 1}$ & 4,028 & 228,689 & 1.8 \\
$\mathbf{1 9 9 2}$ & 4,754 & 227,912 & 2.1 \\
$\mathbf{1 9 9 3}^{*}$ & $5,286^{*}$ & 223,787 & $2.4^{*}$ \\
\hline
\end{tabular}

There was an increasing trend in the use of suspensions on secondary school students.

Table 17 Variance in Total Suspensions from NZ State Secondary Schools 1991-1993

\begin{tabular}{llll}
\hline & Secondary Suspensions & Variance & $\%$ \\
\hline $\mathbf{1 9 9 1}$ & 4,028 & & \\
$\mathbf{1 9 9 2}$ & 4,754 & +726 & +18 \\
$\mathbf{1 9 9 3 ^ { * }}$ & $5,286^{*}$ & $+532^{*}$ & $+11.2^{*}$ \\
\hline
\end{tabular}

When the variance in the use of suspensions in secondary schools is compared with the variance in the secondary school population, it can be seen that while the secondary school roll fell, the number of suspensions increased.

Table 18 Variance of the NZ State Secondary School Roll, and the Variancein the Number of Notified Suspensions 1991-1993

\begin{tabular}{lcc}
\hline & \% Variance in Roll & \% Variance in Suspensions \\
\hline $\mathbf{1 9 9 1 - 1 9 9 2}$ & -0.3 & +18 \\
1992-1993* $^{*}$ & $-1.8^{*}$ & $+11.2^{*}$ \\
\hline
\end{tabular}

The chances of a secondary student being suspended for an unspecified period are quite high. In 1992, one in 167 secondary school students received an unspecified suspension. Projected figures for 1993 indicate that its use may be increasing.

Table 19 Unspecified Suspensions from NZ State Secondary Schools, by Secondary School Population

\begin{tabular}{lccl}
\hline \multicolumn{2}{c}{$\begin{array}{c}\text { Unspecified Secondary } \\
\text { Suspensions }\end{array}$} & Secondary Population & $\%$ \\
\hline $\mathbf{1 9 9 1}$ & 1,133 & 228,689 & 0.5 \\
$\mathbf{1 9 9 2}$ & 1,465 & 227,912 & 0.6 \\
$\mathbf{1 9 9 3}^{*}$ & $1,704^{*}$ & 223,787 & $0.8^{*}$ \\
\hline
\end{tabular}

From mid-1991 the Ministry of Education requested that schools provide information on the gender and ethnicity of suspended students. Since the accuracy of the 1991 gender and ethnicity figures cannot be guaranteed, they (marked ${ }^{* *}$ ) can only tentatively be compared with those notified in 1992. Given that the 1993 figures are also estimated, any annual comparisons using gender or ethnicity would be questionable. We can however examine and comment on the suspension figures for 1992.

Figures returned for 1992 show that in New Zealand schools, boys were suspended three times more frequently than girls. 3,814 male students were suspended compared with 1,268 female students. 
Analysis of the 1992 state primary school suspension figures by gender reveals that in 1992, the ratio of boys to girls being suspended was 8:1. If projected figures for 1993 are correct however, it may be that the percentage of female students being suspended is increasing. Research must examine the reasons for this. Are girls generally better behaved in school than boys and therefore are less likely to come before a principal for serious discipline infringements? Are girls treated more leniently by principals with punishments other than suspension to resolve ongoing problems or to deal with serious infringements?

Table 20 Total Suspensions in NZ State Primary Schools, by Gender

\begin{tabular}{llll}
\hline & Males & Females & Total \\
\hline 1991* $^{*}$ & $239(89 \%)^{* *}$ & $30(11 \%)^{* *}$ & $269^{* *}$ \\
1992 $^{*}$ & $276(84 \%)$ & $52(16 \%)$ & 328 \\
1993* $^{*}$ & $322(78 \%)^{*}$ & $92(22 \%)^{*}$ & $4141^{*}$ \\
\hline
\end{tabular}

While the ratio of boys to girls receiving suspensions in state primary schools in 1992 was 8:1, in state secondary schools in 1992 the ratio was 3:1. Girls made up 25\% of all secondary suspensions in 1992. Projected figures for 1993 indicate that this ratio of 3 boys to 1 girl remains constant.

Table 21 Total Suspensions in NZ State Secondary Schools, by Gender

\begin{tabular}{llll}
\hline & \multicolumn{1}{c}{ Males } & Females & Total \\
\hline $\mathbf{1 9 9 1}^{*}$ & $3,106(77 \%)^{* *}$ & $922(23 \%)^{* *}$ & $4,028^{* *}$ \\
$\mathbf{1 9 9 2}^{*}$ & $3,538(74 \%)$ & $1,216(26 \%)$ & 4,754 \\
$\mathbf{1 9 9 3}^{*}$ & $3,944(75 \%)^{*}$ & $1,342(25 \%)^{*}$ & $5,286^{*}$ \\
\hline
\end{tabular}

It is not surprising to learn that analysis of unspecified suspensions reveals that girls were far less likely to receive an unspecified suspension than boys. In 1992, 22\% of all unspecified suspensions were female. Analysed more fully, in primary and intermediate schools $16 \%$ of unspecified suspensions were girls compared with $22 \%$ in secondary schools.

Table 22 Unspecified Suspensions for the Year 1992, by Gender

\begin{tabular}{lccr}
\hline & $\begin{array}{c}\text { Primary/Intermediate } \\
\text { Unspecified Suspensions }\end{array}$ & $\begin{array}{c}\text { Secondary Unspecified } \\
\text { Suspensions }\end{array}$ & Total \\
\hline MALES & $109(84 \%)$ & $1,138(78 \%)$ & 1,247 \\
FEMALES & $21(16 \%)$ & $327(22 \%)$ & 348 \\
TOTAL & $130(100 \%)$ & $1,465(100 \%)$ & 1,595 \\
\hline
\end{tabular}

Table 22 also shows that of the 348 girls who received unspecified suspensions, only $21(16 \%)$ were primary or intermediate school students.

Information on the ethnic background of suspended students has only been available since mid-1991. As with gender, only a tentative comparison can be made between 1992 notified figures and the estimates for 1991 or 1993.

Table 23 shows that $48 \%$ of all suspended students in 1992 were European, 33\% were Maori and 9\% were Pacific Islanders. 1993 estimates indicate an alarming trend - while the numbers of Maori and Pacific Island students being suspended is increasing, the number of European students being suspended is decreasing. Again, this requires urgent attention by education researchers. Why are Maori and Pacific Island students more likely to be suspended? Do they have lower standards of behaviour in school which make it more likely that they will come to the attention of the principal? Or do racist attitudes either by principals or boards of trustees influence decision-making and make suspension an attractive option for dealing with an errant student? 
Table 23 Total Suspensions in NZ State Schools, by Ethnicity

\begin{tabular}{lllccl}
\hline & European & Maori & Pacific Island & Other & Total \\
\hline $\mathbf{1 9 9 1}$ & $2,790(65 \%)^{* *}$ & $757(18 \%)^{* *}$ & $187(4 \%)$ & $563^{* *}$ & $4,297^{* *}$ \\
$\mathbf{1 9 9 2}$ & $2,413(48 \%)$ & $1,694(33 \%)$ & $469(9 \%)$ & 506 & 5,082 \\
$\mathbf{1 9 9 3}$ & $2,414(42 \%)^{*}$ & $2,136(37 \%)^{*}$ & $584(10 \%)$ & $566^{*}$ & $5,700^{*}$ \\
\hline
\end{tabular}

Further analysis of the 1992 figures reveals that when tested against their own populations, Pacific Island students and Maori students were more likely to be suspended (each 1 in 100) than European students ( 1 in 200).

Table 24 Suspensions for the Year 1992 in NZ State Schools, by Gender

\begin{tabular}{lccl}
\hline & Total Suspensions & Total Population & $\%$ \\
\hline MAORI & 1,694 & 126,176 & 1.3 \\
PACIFIC ISLAND & 469 & 43,694 & 1.1 \\
EUROPEAN/OTHER & 2,919 & 475,443 & 0.6 \\
\hline
\end{tabular}

Analysis of the 1992 notified unspecified suspensions by ethnicity reveals that $45.5 \%$ of all such suspensions were European or "other"; 35.5\% were Maori and 10\% were Pacific Islanders.

Similarly, when suspensions are compared with their own populations, one European student in 500 was suspended for an unspecified period compared with one Pacific Island student in every 250 and one Maori student in every 200.
Table 25 Unspecified Suspensions for the Year 1992 in NZ State Schools, by Ethnicity

\begin{tabular}{lccc}
\hline & Unspecified Suspensions & Population & $\%$ \\
\hline MAORI & 567 & 126,176 & 0.5 \\
PACIFIC ISLAND & 164 & 43,694 & 0.4 \\
EUROPEAN/OTHER & 864 & 475,443 & 0.2 \\
\hline
\end{tabular}

This preliminary analysis has identified several alarming trends with regard to school suspensions and expulsions which require urgent attention. The obvious gender imbalance in the application of suspensions must be addressed. Similarly the preponderance of Maori and Pacific Island students among the suspended population must also be carefully examined. Both trends raise important equity issues.

Figures for unspecified suspension by gender and ethnicity reveal a slightly higher rate $(25 \%)$ of female Maori suspensions out of the total Maori suspensions for 1992, than the 19.5\% and $20 \%$ of the other groups.

Table 26 Unspecified Suspensions for the Year 1992 in NZ State Schools, by Gender and Ethnicity

\begin{tabular}{llccc}
\hline & Maori & Pacific Island & Eur/Other & Total \\
\hline MALES & 425 & 132 & 690 & 1,247 \\
FEMALES & 142 & 32 & 174 & 348 \\
TOTAL & $567(35.5 \%)$ & $164(10 \%)$ & $864(54 \%)$ & $1,595(100 \%)$ \\
\hline
\end{tabular}

\section{Suspensions - Procedural Problems And Legal Challenges}

In the first section I outlined the statutory obligations of principals and boards under the Education Act, 1989. The second section examined current suspension trends using the most recently 
available figures trom the Ministry of Education on notified suspensions and expulsions. As well as the alarming differences between boys and girls and between different ethnic groups, it was quite apparent that an increase in suspensions means more work for principals and of course, more complex procedural problems for discipline committees or boards of trustees to wrestle with.

As well as explaining the statutory responsibilities on boards and principals, the 1991 guidelines from the Ministry of Education also outline procedures for dealing with suspensions and expulsions. Although not mandatory, the Ministry's introduction makes the suggestion that

All members of boards of trustees should have the opportunity to become familiar with them (p. 3).

Specifically, the Ministry suggests:

- That boards make policy about the procedures they will follow before reaching a decision on suspensions.

- That boards prepare an information sheet which could be attached to the suspension letter, informing parents and the student of their rights.

- That suspensions involving special education students be referred to the Special Education Service for guidance prior to any decision.

- That the principal's report be made available to the student and parents prior to the discipline meeting to allow them time to study it - a minimum of 24 hours is suggested.

- That principals adopt culturally sensitive practices which allow for iwi, hapu, whanau, or aiga (Samoan extended family) to be present.

- Although there is no requirement, that the student be encouraged to attend the meeting.

- That the decision to lift or extend an unspecified suspension be a board decision to be made at a meeting of the board.
While not all board members need to be present, a quorum is required.

- That where a disciplinary committee has been established, all board members on that committee be present at the meeting.

- That boards invite an independent person to act in a facilitative role at the discipline meeting. Such a person would be excluded from the actual decision-making.

- That boards establish procedures for disciplinary meetings and decide on the presence of the principal, parents and student during decision-making.

- That it is unwise for the principal to remain with the other board members when they are making their decision. He or she may be seen as prosecutor and judge and there may be concern that information may be passed on that was not brought out at the meeting.

- That the board take care to preserve confidentiality of private information relating to the student or the student's parents. The board can exclude the public from the part of the meeting where the suspension is discussed and/or decided on. Involved parties can remain or be asked to leave.

- That boards reflect the ethnic and socio-economic nature of their communities and the gender/balance of the nation so far as possible and that any disciplinary committee reflect the nature of the school's community.

- That if the board decides to reinstate a student with conditions these conditions should not be made unfair or excessively punitive.

- That the shorter the time lapse between the suspension/ expulsion of a student from one school and his or her enrolment at another the better for the student's educational opportunities. 
Whether a principal or board follows the Ministry's suggested procedures remains a decision for individual principals and boards however. Some schools do, many don't. Indeed, some school boards are not issued with the Ministry Guidelines and would be therefore unaware of the suggested procedures. It may be because of this that boards are liable to make procedural errors. Indeed, Thirty Common Mistakes Made by Schools in Suspension/ Expulsion Procedures (Ludbrook, 1993) currently has a widening circulation.

As long as schools meet the legislative requirements, at present there are no definitive procedures that principals or boards must follow in suspension cases. Herein may lie some of the problems. The Ministry guidelines embody the principles of natural justice. If they are not followed, is the suspended student getting a fair hearing? Are lay board members entirely conversant with the Education Act? Do they receive enough - or any training to enable them to make informed decisions on discipline cases?

Groups such as Auckland's Youth Law Project and the Parent Advocacy Council (now defunct) have published several useful papers on suspension procedures outlining the responsibilities of the principal and the board under the Education Act and the rights of the suspended student. Again however, since each board is responsible for its own procedures, the suspended student and his or her parents or caregivers cannot know in advance what those particular procedures are to be until the principal and board informs them. How students and their families are so informed is again, up to the individual board.

Many of the legislative requirements of the 1989 Education Act have not yet been legally tested. It was inevitable therefore that sooner or later suspension issues would reach the High Court. One recent suspension decision at Palmerston North Boys' High School has now entered New Zealand case law. In the case, the principal suspended two students for consuming small amounts of alcohol on a school ski trip. Both boys were suspended for an unspecified period for their "gross misconduct which is a harmful and dangerous example to other students". Central to the case was the fact that Palmerston North Boys' High had a specific rule which made it clear that possession of, trading in or use of alcohol would result in suspension.

In November 1990, in the Wellington High Court, Justice McGechan (High Court of New Zealand, 1990, pp. 58-59) found in favour of both boys and quashed both the decision of the principal to suspend them for an unspecified period and the decision of the board of trustees to expel one and extend the suspension of the other.

He held that while schools may have a general policy towards alcohol or drugs, cases may not be resolved automatically in accordance with such policy. In every suspension case, principals and boards must consider

all the circumstances of each individual case before deciding whether or not individual alcohol related conduct amounts to gross misconduct.

Justice McGechan also held that, even where gross misconduct or dangerous example have been found to exist, neither principals nor boards should automatically suspend a student, but instead, apply discretion.

At each discretionary stage, special circumstances and considerations of humanity and mercy may be brought into account.

In summing up, Justice McGechan warned that the statutory approaches embodied in the Education Act were designed for the protection of children.

They are not to be sacrificed to administrative or disciplinary efficiency, or some supposed need for absolute certainty. Results must not be fixed: they must instead be fair.

The Palmerston North case serves as a reminder to all principals and boards that the principles of natural justice must 
apply at all stages of the disciplinary process. It is not enough simply to obey the raw letter of the law.

A second case heard in March 1993 in Chambers in the Wellington High Court involved a student from a college in Wairarapa. In November 1992, a 14-year-old third form student was suspended by the principal for an unspecified period for the alleged trading of a small amount of marijuana: “... because of his behaviour it was likely that the student or other students would be seriously harmed if he was not suspended." The board of trustees upheld the suspension and suspended the student until age 16.

The student applied for reinstatement at the college through the High Court pending a Judicial Review. A range of procedural matters were discussed at the hearing including the applicant's belief that

a) the original subcommittee of the board did not have delegated authority to suspend him;

b) there were insufficient grounds to find that unless he was suspended, it was likely that other students would be seriously harmed.

Justice Greig (High Court of New Zealand, 1993, pp. 7-8) found against the student in the case and relief was not granted. In a reserved judgment of April 23 1993, Justice Greig held that the College's discipline committee did have delegated authority. He further held that the principal and the board of trustees had evidence and information upon which they could properly form an opinion that the student's behaviour was likely to cause serious harm to other students if his suspension did not continue. Justice Greig reminded everyone that boards of trustees were not lawyers, nor did they need to be.

The words used in the statute are words of ordinary import which do not, I think, require any analysis to extract their meaning. It is to be remembered that they are to be applied by lay people, not lawyers, who have the control and management of the school and the supervision of the pupils together.
A full Judicial Review of this student's case had not been heard at the time of writing.

The Ombudsman has also ruled on a suspension case. At Upper Hutt College, in May 1992, a 15-year-old student was expelled for "gross misconduct" after he admitted bringing the drug datura into school and offering it to another student. The boy's parents made a formal complaint to the Ombudsman in July 1992. The Ombudsman Sir Brian Elwood ruled in May 1993 that the boy's expulsion was contrary to the provisions of the Education Act 1989, that the statutory requirements for gross misconduct had not been reasonably met and that the school may have acted contrary to the principles of natural justice.

[A] disproportionate weight appeared to have been given to the school policy on drugs, which suggested that the requirements of the Act were pre-empted. All the evidence the school had was the student's admission that he had used datura. (Evening Post, 1993)

The Ombudsman recommended that the student be reinstated. The Upper Hutt College board of trustees rejected the Ombudsman's ruling and refused to reinstate the student. According to the board chairman Dr Basil Walker, as reported in the Dominion newspaper,

nothing from the Ombudsman convinced the board it made the wrong decision. Under the same circumstances, the same decision would be made. The board that expelled the boy had since completely changed, but the new board unanimously agreed with the decision ... The Ombudsman is obliged to make his finding. But the board is also obliged to decide as best fitting the circumstances under the law, and for the school. (Dominion, 1993)

While principals and board members may not need to be lawyers, there are very complex issues involved in suspension cases, particularly given that the principal and board have discretion to interpret the Education Act. Moreover, increased use of suspension means more work for principals and boards and 
therefore an increasing need to make sure that suspension procedures are clearly understood by all parties.

There is no doubt that in New Zealand state schools a great deal of time and energy is taken up in ensuring that statutory requirements with regard to suspensions are met. Within seven days of a student being suspended for an unspecified period, the principal and the board of trustees or their delegated committee must meet with the student's parents or caregivers to hear the case and make a decision as to whether to uphold the principal's decision. The board must then meet all its statutory obligations under the Education Act and - as Justice McGechan pointed out - they must also act in a procedurally correct and fair manner. But the question remains, are principals and boards conversant enough with the Education Act and the Ministry of Education guidelines to handle suspension cases properly and fairly?

If the suspended student or his or her family perceives that the board's statutory obligations have not been met or that there were inadequacies in the procedure followed, the board and principal may find themselves presented with a request for a review of the decision either by the full board, by the Ombudsman or by the High Court of New Zealand.

Obviously, suspension matters are sensitive issues. How a board deals with a case is carefully scrutinised by the student and his or her family and supporters. If the principal and board are perceived to have got it wrong, the media may become involved as a lobby group to highlight grievances. The case of the student in Wairarapa received widespread media coverage. Added pressures have also been recently applied to principals and boards by the Privacy Act and the Official Information Act which require that all appropriate written information held by the college be readily accessible to applicants. What may therefore begin as a "simple" clear-cut suspension case for board members can easily turn into a complex minefield open to public debate.
There is a real need for principals and boards of trustees to align their procedures as closely as possible to the Ministry of Education's guidelines to ensure not only that correct procedure is followed but also that they follow the principles of natural justice. However, as I have stated, there is no obligation on schools to follow the Ministry's guidelines. Some school boards are not even issued with them. How closely then do school principals and boards of trustees follow the Ministry of Education guidelines on suspensions and expulsions? Are all boards actually aware of them? What role does the School Trustees' Association play in training boards of trustees to deal with complex discipline issues? The recent STA handbook (NZSTA, 1993) seems to have all but avoided discussing procedural issues relating to suspensions.

This initial foray into the area of discipline matters has highlighted the great need for further research in many areas. One important investigation which has yet to be carried out is into the effects of suspension on a student and his or her family. What effect does the suspension of a primary or intermediate school student have on his or her future education?

A worrying trend which also needs careful study is those students who "hop" from school to school being suspended from each. What ultimately happens to a student who is suspended or expelled from one school and is then suspended or expelled from subsequent schools?

Finally, there is a need for an agency or education ombudsman to monitor suspensions and expulsions and be assigned power by Government to implement its recommendations. At present the Education Review Office monitors state school suspensions through their assurance audits. While such an audit certainly ensures that the school has met its statutory obligations under the Education Act, it does not address procedures. Who is therefore to ensure that the principal and board follow the principles of natural justice in meeting those statutory obligations? The Palmerston North judgment was a reminder to all principals and boards that in suspension cases it 
is not enough to meet all the statutory obligations. Discretion has to be applied "and humanity, mercy and special circumstances may be brought into account." (High Court of New Zealand, 1990, p. 58)

To end, I return to the philosophical basis of the 1989 Education Act. Before any suspension is enacted by a principal or board it is worth remembering that the principal and board also have a duty to ensure that "all students have assistance to remain at school and progress with their learning." (Ministry of Education, 1991, p. 3)

\section{Notes}

1. The Ministry of Education's Guidelines For Suspensions And Expulsions (1991) states that "state school principals must take all reasonable steps to ensure that parents are told of matters that in the principal's opinion are 'preventing or slowing the student's progress through the school' or are 'harming the student's relationship with teachers and other students'." (p. 3) It further states that "If the school fails to keep parents/caregivers informed of problems with the student's behaviour or progress and allows a situation to develop until the student is threatened with suspension from the school, the parents may argue that the school has failed in its legal duty to the parents and therefore cannot seek to suspend the student from the school without giving the parents the opportunity to use their parental authority or family resources to deal with the problems." (pp. 3-4)

2. The Secondary Principals' Association of New Zealand's Guidelines On Suspension And Expulsion Procedures (1991) under "Student Misbehaving" states that "Section 77 (of the Education Act) requires that parents are told of factors causing concern. Copies should be kept of letters and telephone calls logged." (p. 12)

3. The Ministry of Education's Guidelines For Suspensions And Expulsions (1991) states that "state school principals must take reasonable steps to ensure that students get good guidance and counselling." (p. 3) and further that "If the school has failed to provide guidance and counselling for the student as a means of dealing with the problem any attempt to exclude the student may be countered by the parents on the basis that the student has been denied the right to guidance and counselling and that this should be offered before exclusion is considered." (p. 4)
4. The Secondary Principals' Association of New Zealand's Guidelines On Suspension And Expulsion Procedures states that Counselling and Guidance are required "in all circumstances - no necessary connection with suspension/expulsion. The requirement can be fulfilled in a variety of ways: Deans, Form Teachers, Class Teachers, Assemblies, Student Handbooks, Newsletters, Prospectuses, School Reports, Curriculum areas e.g., Health Programme, etc." It further suggests under "student misbehaving", however, to "check that the counsellor sees repeated misbehaviours. Note dates." (p. 12)

\section{References}

The Dominion, 4 June, 1993

Dunphy, Ann The Principal's Role in Suspensions and Exclusions, Penrose High School, 1992.

The Evening Post, 4 June, 1993

High Court of New Zealand, Reserved Judgment of Greig, J. April 25, 1993 , in the case of " $\mathrm{A}$ " against "B" principal and " $\mathrm{C}$ " Board of Trustees, March 25, 1993.

High Court of New Zealand, Reserved Decision of McGechan, J. in the case of "M" and "R" against David A Syms and the Board of Trustees of Palmerston North Boys' High School, 5 December 1990. (Postscript to Justice McGechan's reserved decision available from the Ministry of Education, Box 1666, Wellington)

Jefferson, Simon School Suspensions and Expulsions Paper given at the School Expulsions and Suspensions Seminar, 24 September, 1992.

Ministry of Education, Guidelines For Suspensions and Expulsions, 1991. (Available from the Ministry of Education, Box 1666, Wellington)

New Zealand School Trustees Handbook, 1993. (Available from the New Zealand School Association Trustees Association, PO Box 5123, Wellington)

Parent Advocacy Council, Suspension and Expulsion, 1991. (Available from the Ministry of Education, Box 1666, Wellington)

School Principals' Association of New Zealand, Guidelines For Suspension And Expulsion Procedures, 1991. (Available from the School Principals' Association, Box 9046, Newmarket, Auckland) 
(The publications listed below are available from the Youth Law Project, PO Box 74-328, Auckland 5)

Ludbrook, Robert, Thirty Common Mistakes Made By Schools In Suspension/Expulsion Procedures. Paper given at the School Expulsions and Suspension Seminar, September 24, 1992.

Youth Law Project, School Expulsions - An Advisor's Guide, Project (1992) Summary of legal and procedural requirements for school expulsions and suspensions with an outline of the legal rights of parents and children.

Youth Law Project, Kicked Out Of School, Brief summary of students' rights on expulsion.

Youth Law Project, Survey of School Suspensions and Expulsions in Auckland Secondary Schools, 1990.

\section{The author}

Cathy Casey was awarded her doctorate in Sociology from Aberdeen University, Scotland in 1984. Since then she has held several research fellowships at Universities in Scotland and New Zealand. In 1991 she gained her registration as a secondary teacher and presently teaches at Makoura College in Masterton. In October 1992 she was elected as a parent representative on to the board of trustees at Kuranui College in Greytown. 